\title{
Communication Policy: the Efforts to Strengthen Civil Society
}

\author{
Teguh Ratmanto
}

\begin{abstract}
In the last decades there were a tendency to make public institution more open and greater public participation in decision making. It is believed that transparency is the only way to strengthen public institutions which it is highly possible because of the progress in Information and Communication Technology. Nowadays Indonesia is entering the Era of Opennes. The idea of civil society and establisihng social welfare which is the first priority require partnership between the government and public. The whole stakeholder should cooperate to improve accessibility on ICT and should develope information and communication infra structure, and should improve application of ICT in every aspect of public services
\end{abstract}

Kata kunci: public institution, public participation, ICT, civil society

\section{Back ground}

In the last decade, there is a tendency in many countries to be more open. During that time, either individual or group of people demand public institution to be more responsive and responsible, and they want to be involved in the decision making process. They believe that sharing public information between the government and public will contribute to a better participation in the development which is based on qualified public decisions. They also encourage transparency as a means to strengthen integrity of public institutions. The movement to implement better, open, and transparent government is supported by the rapid progress in Information and Communication Technology in which transmitting and managing information become primary driven of the changing.

In general, nowadays people aware that they have rights to know and to influence decision making process on everything concerning their interests. Their right is guaranteed in an International Agreement on Civil and Politic Right which declares that every person has right to express their opinion, this right including freedom to search, to express, and to gain information and ideas, without limitation, whether oral, written, or printed in any form of media or art. The tendency of being more transparent and global communication revolution has increased public expectations about coverage and provision of information which are served by public institutions.

Public officials have recognized the significance of free flow of information. The Initiative of Ministers of Economic Cooperation of APEC which was held on October 2003, for example, had declared transparency as an important thing to 
accelerate economic growth and monetary stability. This condition which is conducive for just and effective governance will in turn increase public trust to government (Declaration of APEC on Standard Transparency, October 2003).

Along with the decade of Openness and Transparency in the region, Indonesia sees "Reformation Era" which is a new phase in the history of Indonesia. Suharto's regime which have come into power for more than three decades suddenly fall down and leave the country in an chaotic condition. After more than three decades under authoritarian, closed political and communication policy which is anti criticism the public find itself free. Printed and broadcasting media which were haunted by government censorship, suddenly are being freed of government surveillance. The Indonesian Government released the Press Act in 1999 (Act no. 40/1999 about Press) which was followed by The Broadcasting Act in 2002 (Act No. 32/2002 about Broadcasting), and now is being discussed in the parliament the Draft of The Freedom to Access Public Information Act. There are changing of political paradigm of government from what to tell to what to listen.

On one hand, it seems to be that public sphere begin to flourish in Indonesia since the "Reformation Era" and public awareness on their rights is increasing. However, on the other hand, there are some old-style people who want to set back to the previous era. This indication is quite obvious when there are some obstacles to legalize the draft of The Freedom to Access Public Information Act into The Freedom to Access Public Information Act which will facilitate and guarantee access to public information. The access to public information will contribute to the maintaining and broadening of the public sphere.

According to Habermas (in Kunelius and Spark, 2007), public sphere is a realm of social life in which something approaching public opinion can be formed. Access is guaranteed to all citizens. Citizens act as a public body when they confer in an unrestricted fashion about matters of general interest. It could happen because there are the guarantee of freedom of assembly and associa- tion and the freedom to express and publish their opinions. In a large public body, this kind of communication requires specific means for transmitting information and influencing those who receive it. Today, newspapers, magazines, radio, and television function as the media of the public sphere which mediates between society and state, in which the public organizes itself as the bearer of public opinion, accord with the principle of the public sphere. This principle of public information has to be fought for against the arcane policies of government and since that time it has made possible public control of state activities. The political power of the state in fact should be controlled to avoid of abusing of power which is indicated by Castell (in Kantola, 2007) that, "The 1990s have testified to widespread suspicions about national politics. Politics have been be infected by political scandals having to do with personal issues." It seems to be that the emergence of civil society which is based on the awareness that establishing social welfare and justice by government is not a simple effort. Strengthening the relationship between a government and its citizens might seem to be such an obvious priority for democracies that it hardly needs spelling out. Yet governments everywhere have been criticised for being remote from the people, not listening enough and not seeking participation. Street protests which may have grabbed most of the headlines, show a steady erosion of voter turnout in elections and falling membership in political parties.

There are some states which endeavor to establish welfare for their citizens while some other ignore it. Citizens become inferior before the state. Bureaucracy and state apparatus which should establish social welfare and justice in fact they are a means of the ruling class.

\section{Theoretical Framework}

In communication, we understand that "We can not not communicate" which means that communication is a necessity and it is a condition sine qua non for social interaction. Communication is a basic right for any individual. Democratic government system requires communication freedom for 
Terakreditasi Dirjen Dikti SK No. 56/DIKTI/Kep/2005

its sustainability. This right can be traced back to the classic era of democracy in Athen. The right to communicate, in a democratic regime, is undeniable because it, philosophically, is characterized by the principle of pluralism.

In a democratic and having freedom of communication environment, it is believed that the political element of many civil society organizations will facilitate better awareness and well-informed citizenry who will make better public decision and increasing public participation in politic. Therefore, civil society has significant role in producing social capital and, in turn, the social capital will strengthen to civil society. A low level of social capital will result in unresponsive political system and high levels corruption. Formal public institutions require social capital in order to function properly.

In this context, the concept of civil society is almost similar to gemeinschaft or mezzostructure, that is a form of social grouping which is more complex compared to family. Civil society refers to arena of uncoerced collective action. In theory, its institutional forms are distinct from those of the state, family, and market, though in practice, the boundaries among state, civil society, family, and market are often complex and blurred. However, this kind of social grouping is not rigid and too formal as it is usually developed by state (Sztompka, 1998:191). Implicitly, the ideological message in it is to liberate people and to fight against any colonization on human life and to establish public solidarity. The concept of civil society can not be separated from the concept of public sphere. Kantola (2007) believes that "At the moment it seems like the most popular ideas to characterize the public sphere in the new situation come at this point from the ideas of civil society which seem to gain popular acceptance (see Fairclough 2000, 79; Clarke, Newman 1997, 123 139). These ideas of civil society are reflected in many theories of the public, which see it as an independent arena for public opinion building." This means that an independent public participation in democracy is a must. However it is not just participation. Coleman (in Dahlgreen 2007:21) wrote that 'Too often 'engagement' is discussed and promoted in an uncritically normative fashion, as if to engage is inherently good thing." This means that citizen participation can not be understood good thing as such but things that good on conditions. Furthermore, he (in Dahlgreen 2007:21) believed that

"Democratic power is legitimized through mass participation, but when voluntary engagement takes the form of collusion with manipulative authority, power ceases to be accountable and the autonomous citizen begins to look more like a slavish subject."

In a multiethnic and newly-learned democracy, such as Indonesia, it is an important thing to emphasize on what Putnam (2000) categorized as bonding and bridging capital. The decreasing quality of both will be a potential source of deviation such as paid street protesters who rally for money not for issue. Communication, therefore, is needed to access and use social capital through exchanging information, identify problems and solutions, and manage conflict. Furthermore, Putnam (2000) argued that the decline of bonding and bridging capital will lead to low distrust which will contribute to lower levels of trust in government and lower levels of civic participation.

However, in terms of Information and Communication Technology, Chadwick (2006:26) believed that "Particularly blogs (create) a different sort of environment, which appears to have lowered level of apathy and increased citizen participation" Furthermore, he (2006:84) believed the potential of the Internet to enhance "community cohesion, political deliberation, and participation" by providing horizontal linkage between citizens in civil society as well as the vertical linkages between civil society and policy makers. Meanwhile, Dahlberg and Siapera (2007:7) believed that

"the primary concept of citizen participation revolves around online actions that can challenge paradigms and policies of the capitalist-political order -or to frame it in terms of an academic imperative, the must of 'ongoing reflection on the conceptualization and realization of equality, liberty and democratic community."

The radicalization of democracy comes down 
from a notion of emancipated citizenship which displayed in terms of readiness and competence to convey the vox populi vis-à-vis the powers, and to insist just allocation of it.

For these reasons, Kantola (2007) believes that public sphere has an important role to play when considering the practical survival of liberal democracies: public sphere is the site of political life and legitimization in modern mass democracies. By keeping public sphere politically alive and kicking as well. And vice versa: if politics disappear from public places, politics take behind the curtains and thus the life and legitimacy of the political system is in jeopardy. Meanwhile, according to Ward (2007),

"In a democratic and open society an individual is entitled to both access and impart information in an uncoerced manner. The role of any State, governed by the normative requirements of a democratic system of government, must be to determine the nature of the institutions that are acceptable on social policy grounds, in order to accomplish a set of conditions that allow the individual to participate in public debate as fully as possible. A number of policy objectives therefore arise as prerequisites for democratic communication. These include (1) the right to universal access on a nonexclusive basis to a basic television service, (2) the right to a plurality of information from a number of sources, and (3) the right to have access to a diverse and quality range of information ... which in turn require behavioral and structural regulation." On the other hand, Chadwick (2006) argued that availability and accessibility of the internet is a prerequisite of online participation. It is government duties to provide access to public information through technology (ICT).

The term of media \& communications policy refers to the general principles which guide decisions of authorities, usually governments, about the function of the mass media. The objects of media policy are understood to be content, ownership of the media industries, matters of technical infrastructure, and technological development, the relationship of the media with the public as well as matters regulating the relationship of the media with authorities and the market.

The study of media policy borrows from soci- ology, political sciences, anthropology, and history. It involves the study of decisions regulating (or not regulating) media content, such as the broadcast of pornographic material or violence on day-time television, decisions that organize the media landscape into public and private organizations depending on the forms of ownership and those that guarantee or restrict the freedoms associated with expression, whether artistic or journalistic. Media policy, furthermore, refers to the set of norms and institutions that administer or manage the rights and obligations of media professionals and organizations, aiming at maintaining journalistic ethics, advertising standards, and generally by (usually) self-regulating the relationship of the media with their publics.

Although media policy is usually made by national governments, it can also be made by statelike formations such as the European Union, or international organizations, such as the WTO, as well as by the media themselves in their organization of professions and industries. The study of media policy expands to cover the processes of policy-making, which involves actors and institutions as well as the set of values and beliefs that underlie the justification of certain decisions. More neglected is the systematic study of the effects of media policy for audiences as consumers of the media and as citizens who depend on the media for accurate information.

With the development of convergent technologies, such as computers, media policy covers areas such as the trafficking of personal data for commercial purposes, through the unauthorized monitoring of communicative activity, commercial or other, over the internet but also the monitoring of use habits of new media (computer, mobile phones and integrated media systems) by state authorities. Increasingly, media policy is thought to constitute part of citizenship policy especially when it has an impact on civil liberties and human rights.

\section{An Information Society for All: Key Principles}

We are resolute in our quest to ensure that 
Terakreditasi Dirjen Dikti SK No. 56/DIKTI/Kep/2005

everyone can benefit from the opportunities that ICTs can offer. We agree that to meet these challenges, all stakeholders should work together to improve access to information and communication infrastructure and technologies as well as to information and knowledge; to build capacity; to increase confidence and security in the use of ICTs; to create an enabling environment at all levels; to develop and widen ICT applications; to foster and respect cultural diversity; to recognize the role of the media; to address the ethical dimensions of the Information Society; and to encourage international and regional cooperation. We agree that these are the key principles for building an inclusive Information Society.

(1) The role of governments and all stakeholders in the promotion of ICTs for development. Governments, as well as private sector, civil society and the United Nations and other international organizations have an important role and responsibility in the development of the information society and, as appropriate, in decision-making processes. Building a people-centred information society is a joint effort which requires cooperation and partnership among all stakeholders.

(2) Information and communication infrastructure: an essential foundation for an inclusive information society.

Connectivity is a central enabling agent in building the information society. Universal, ubiquitous, equitable and affordable access to ICT infrastructure and services, constitutes one of the challenges of the information society and should be an objective of all stakeholders involved in building it. Connectivity also involves access to energy and postal services, which should be assured in conformity with the domestic legislation of each country.

A well-developed information and communication network infrastructure and applications, adapted to regional, national and local conditions, easily-accessible and affordable, and making greater use of broadband and other innovative technologies where possible, can accelerate the social and economic progress of countries, and the well-being of all individuals, communities and peoples.

Policies that create a favourable climate for stability, predictability and fair competition at all levels should be developed and implemented in a manner that not only attracts more private investment for ICT infrastructure development but also enables universal service obligations to be met in areas where traditional market conditions fail to work. In disadvantaged areas, the establishment of ICT public access points in places such as post offices, schools, libraries and archives, can provide effective means for ensuring universal access to the infrastructure and services of the information society.

(3) Access to information and knowledge The ability for all to access and contribute information, ideas and knowledge is essential in an inclusive information society.

The sharing and strengthening of global knowledge for development can be enhanced by removing barriers to equitable access to information for economic, social, political, health, cultural, educational, and scientific activities and by facilitating access to public domain information, including by universal design and the use of assistive technologies. A rich public domain is an essential element for the growth of the information society, creating multiple benefits such as an educated public, new jobs, innovation, business opportunities, and the advancement of sciences. Information in the public domain should be easily accessible to support the Information Society, and protected from misappropriation. Public institutions, such as libraries and archives, museums, cultural collections and other community-based access points, should be strengthened so as to promote the preservation of documentary records and free and equitable access to information.

Access to information and knowledge can be promoted by increasing awareness among all 
stakeholders of the possibilities offered by different software models, including proprietary, open-source and free software, in order to increase competition, access by users, diversity of choice, and to enable all users to develop solutions which best meet their requirements. Affordable access to software should be considered as an important component of a truly inclusive Information Society. We strive to promote universal access with equal opportunities for all to scientific knowledge and the creation and dissemination of scientific and technical information, including open access initiatives for scientific publishing.

\section{(4) Capacity building.}

Each person should have the opportunity to acquire the necessary skills and knowledge in order to understand, participate actively in, and benefit fully from, the information society and the knowledge economy. Literacy and universal primary education are key factors for building a fully inclusive information society, paying particular attention to the special needs of girls and women. Given the wide range of ICT and information specialists required at all levels, building institutional capacity deserves special attention. The use of ICTs in all stages of education, training and human resource development should be promoted, taking into account the special needs of persons with disabilities and disadvantaged and vulnerable groups.

Continuous and adult education, re-training, life-long learning, distance-learning, and other special services, such as telemedicine, can make an essential contribution to employability and help people benefit from the new opportunities offered by ICTs for traditional jobs, self-employment and new professions. Awareness and literacy in ICTs are an essential foundation in this regard. Content creators, publishers, and producers, as well as teachers, trainers, archivists, librarians, and learners, should play an active role in promoting the information society, particularly in the Least Developed Countries.
To achieve a sustainable development of the Information Society, national capability in ICT research and development should be enhanced. Furthermore, partnerships, in particular between and among developed and developing countries, including countries with economies in transition, in research and development, technology transfer, manufacturing and utilization of ICT products, and services are crucial for promoting capacity building and global participation in the information society. The manufacture of ICTs presents a significant opportunity for creation of wealth.

The attainment of our shared aspirations, in particular for developing countries and countries with economies in transition, to become fullyfledged members of the information society, and their positive integration into the knowledge economy, depends largely on increased capacity building in the areas of education, technology know-how and access to information, which are major factors in determining development and competitiveness.

The significant of Communication Policy to guarantee of Communication Rights:

(1) Mass Media are now dominated by a few global corporations. This is significantly biases contents towards profit generation and reduces diversity of sources and content.

(2) Mass media play a growing role in identity formation and cultural processes, but these are shifting towards an unsustainable individualist and consumerist ethos.

(3) The ongoing extension of copyright duration and stiffer enforcement in the digital area, is impending communication and the use of knowledge, and the public domain is shrinking.

(4) Access to ICTs, and their use to tackle poverty and exclusion, has almost ground to a halt under neo-liberal policies.

(5) Under the pretext of a "war on terrorism", civil rights in the digital environment are being severally eroded.

In a worst-case scenario, the risk to society is great. A severe deterioration in the communi- 
Terakreditasi Dirjen Dikti SK No. 56/DIKTI/Kep/2005

\begin{tabular}{|c|c|c|c|}
\hline \multicolumn{4}{|c|}{ BASIC FRAMEWORK STRUCTURE } \\
\hline $\begin{array}{l}\text { Communicating in } \\
\text { Public Sphere }\end{array}$ & $\begin{array}{l}\text { Communicating } \\
\text { Knowledge }\end{array}$ & $\begin{array}{l}\text { Civil Rights in } \\
\text { Communication }\end{array}$ & $\begin{array}{l}\text { Cultural Right in } \\
\text { Communication }\end{array}$ \\
\hline $\begin{array}{l}\text { 1. Freedom of } \\
\text { Expression. }\end{array}$ & $\begin{array}{l}\text { 1. A balanced } \\
\text { knowledge-sharing } \\
\text { regime, with practical } \\
\text { support measures. }\end{array}$ & $\begin{array}{l}\text { 1. Right to equality } \\
\text { before law, to honor and } \\
\text { reputation. }\end{array}$ & $\begin{array}{l}\text { 1. Communicating in } \\
\text { one's mother tongue. }\end{array}$ \\
\hline $\begin{array}{l}\text { 2. Freedom of Press } \\
\text { and Media including } \\
\text { electronics. }\end{array}$ & $\begin{array}{l}\text { 2. Publicly funded } \\
\text { knowledge enter the } \\
\text { public domain. }\end{array}$ & $\begin{array}{l}\text { 2. Information privacy } \\
\text { and data protection. }\end{array}$ & $\begin{array}{l}\text { 2. Participation in the } \\
\text { cultural life of one's } \\
\text { community. }\end{array}$ \\
\hline $\begin{array}{l}\text { 3. Access to, and ready } \\
\text { availability of, public } \\
\text { and government } \\
\text { information. }\end{array}$ & $\begin{array}{l}\text { 3. Affordable and } \\
\text { equitable access to all } \\
\text { media for knowledge- } \\
\text { sharing. }\end{array}$ & $\begin{array}{l}\text { 3. Privacy of } \\
\text { communication. }\end{array}$ & $\begin{array}{l}\text { 3. Stimulate the } \\
\text { sharing of culture and } \\
\text { cultural identity. }\end{array}$ \\
\hline $\begin{array}{l}\text { 4. Access to corporate } \\
\text { information. }\end{array}$ & $\begin{array}{l}\text { 4. Availability of } \\
\text { relevant knowledge for } \\
\text { all communities. }\end{array}$ & $\begin{array}{l}4 \text { Communication } \\
\text { surveillance in public } \\
\text { and workplace. }\end{array}$ & \\
\hline $\begin{array}{l}\text { 5. Diversity and } \\
\text { plurality of media } \\
\text { content. }\end{array}$ & $\begin{array}{l}\text { 5. Widespread skills and } \\
\text { capacities to use media } \\
\text { especially ICTs. }\end{array}$ & & \\
\hline $\begin{array}{l}6 . \text { Universal Access to } \\
\text { relevant media. }\end{array}$ & & & \\
\hline \multicolumn{4}{|c|}{$\begin{array}{l}\text { International dimension of Communication Rights } \\
\text { 1. The role of non-national, transnational and cross border media and } \\
\text { communication } \\
\text { 2. The role and relevance of international agreement }\end{array}$} \\
\hline \multicolumn{4}{|c|}{$\begin{array}{l}\text { Democracy and participation in communication governance } \\
\text { 1. Effective participation by civil society in governance nationally } \\
\text { 2. Effective participation by civil society in governance transnationally }\end{array}$} \\
\hline
\end{tabular}

cation cycle of society could enfeeble democratic debate and participation, undermine creativity, and severely constraint individual and collective mutual understanding. Communication rights underline the role of communication in the reproduction and sustainability of economic, social, cultural and political processes.

\section{Selected Bibliography}

Chadwick, Andrew. 2006. Internet Politics. States, Citizens and New Communication Technologies. New York: Oxford University Press.

Dahlberg, Lincoln and Eugenia Siapera, (eds). 2007. 
Radical Democracy and The Internet. New York: Palgrave Macmillan.

Dahlgren, Peter, (ed). 2007, Young Citizens and New Media: Learning for Democratic Participation. New York: Routledge.

Kantola, Anu. 2007. "Leaving Public Places: Antipolitical and Antipublic Forces of the Transnational Economy" http://www.javnostthepublic.org/media/datoteke/2001-1kantola.pdf. Accessed August 16, 2007.

Kunelius, Risto and Colin Sparks Sphere: An Introduction. 2007. "Problems with A European Public" http://www.javnost-thepublic.org/ media/datoteke/2001-1-kunelius.pdf. Accessed August 16, 2007.
Sztompka, Piotr 1998, 'Mistrusting Civility: Predicament of a Post-comunist Society' in Jeffry C. Alexander (ed) Real Civil Societies, Dilemmas of Institutionalization, 1998.

Ward, David. 2007. "The Democratic Deficit and European Union Communication Policy: An Evaluation of the Commission's Approach to Broadcasting"http://www.javnostthepublic.org/media/datoteke/2001-1ward.pdf. Accessed August 16, 2007.

"Declaration of APEC on Standard Transparency, October 2003" available at http:// $w w w$. apecsec.org.sg/apec/ le a d ers_declaration/ 2003 leadersstmtimplapectranspstd.htm) 